\title{
Synthesis, Characterization and Biological Evaluation of Penicillin Derivatives Complexes with Some Transition Metal Ions
}

\author{
Ammar J. Alabdali and Yasser H. Sabah* \\ Department of Chemistry, College of Sciences, Al-Nahrain University, Baghdad, Iraq \\ *Corresponding author
}

\begin{abstract}
A B S T R A C T
\section{Keywords}

Schiff base,

6-amino

penicillanic acid,

Terephthaldehyde,

Glyoxal,

Metal complexes.

Article Info

Accepted:

18 November 2016

Available Online:

10 December 2016

This study is for the purpose of academic knowledge to know the behavior of some ligands with some metal ions according to the ligands properties as bifunctional antibacterial (two $\beta$-lactams groups) and multidentate linkage; that the two new ligands have been prepared from the interaction of bifunctional aldehyde (terephthaldehyde and glyoxal) with the antibacterial 6-amino penicillanic acid (6APA) to yield $\mathrm{L}_{1}$ and $\mathrm{L}_{2}$ respectively. The bifunctional bidendate-ligands $\mathrm{L}_{1}$ and $\mathrm{L}_{2}$ interacted with $\mathrm{Co}(\mathrm{II}), \mathrm{Cu}(\mathrm{II})$ and $\mathrm{Zn}$ (II) ions under reflux to prepare six new nonelectrolytic complexes with mole ratio $2: 1 \mathrm{M}: \mathrm{L}$ and general formula $\left[\mathrm{M}_{2} \mathrm{~L}_{1} \mathrm{Cl}_{\mathrm{X}}\right.$ $\left.\left(\mathrm{H}_{2} \mathrm{O}\right)_{\mathrm{Y}}\right] \cdot \mathrm{ZH}_{2} \mathrm{O}(\mathrm{x}, \mathrm{y}, \mathrm{z})$ : natural number. The resulting products were characterized using ${ }^{1} \mathrm{H}-\mathrm{NMR}, \mathrm{Uv}-\mathrm{Vis}$ and IR-spectroscopy. Metal and elemental analysis was performed along with molar conductivity and thermal analysis. The results suggested that the complexes could be with distorted octahedral geometry. The microbiological activity of the synthesized compounds have been evaluated in minimum inhibitory concentration (MIC) of the raw material 6-APA as a lead which was $10^{-3} \mathrm{M}$, thus the derivatives were expected to be more active and sensitive against both Gram-positive and Gram-negative organisms at the selected concentration $\left(10^{-3} \mathrm{M}\right)$.
\end{abstract}

\section{Introduction}

Penicillin antibiotics were among the most important treatments to be effective against many bacterial infections, they also considered are among the most frequently utilized and least toxic antibiotics (Flynn $\mathrm{H}$. Edwin, 1972). Compounds containing an azomethine group (imine) played an important role in medicinal and pharmaceutical field.

The biological applications of these compounds have attracted a great attention
(Przybylski et al., 2006; Arulmurugan et al., 2010).

Some Schiff-bases (imine compounds) were exhibit antibiotic, antiviral and antitumor agents because of their specific structure (Parekh et al., 2006; Zhou Xin et al., 2007; Cleiton da Silvaa et al., 2011).

The frequent use of antibiotics was the reason of the greater resistance of bacteria to the drug which resulted in the serious 
medical problem. The synthesis of new derivatives of antibiotics has become an important task to deal with drug resistance problems.

Due to the activities associated with the antibiotics and imines, an attempt was made to synthesize and evaluate the biological activity of some novel Tri-Schiff's basses derived from 6-aminopenicillanic acid (6-APA), the results also showed that the novel tri-Schiff bases have better activity than 6-APA alone (Radwan, 2009).

Another attempt was made to prepare new derivatives containing imine and amoxicillin in the same molecules. The prepared compounds were characterized and the antibacterial activities of these derivatives have good activities when compared to the activity of parent drug (Tomi et al., 2013).

On the last decade some studies focused on the synthesis of complexes from antibiotics only, without modulation or as Schiff base derivatives.

Some Complexes of cephradine with Co(II), $\mathrm{Cu}(\mathrm{II}), \mathrm{Ni}(\mathrm{II})$ and $\mathrm{Zn}$ (II) have been prepared in (1:2) (M:L) molar ratio; all the complexes were octahedral except copper complex was in a square planar geometry. Cephradine and its complexes have been screened for their antibacterial activity against different bacterial strains, the antibacterial results evidently show that the complexation improved the antibacterial activity (Chohan and Jaffery, 2000).

Also there are many studies on the Schiff bases derived from antibiotics and their complexes.

Synthesis of $\mathrm{Co}(\mathrm{II}), \mathrm{Ni}(\mathrm{II}), \mathrm{Mn}(\mathrm{II})$ and $\mathrm{Zn}$ (II) complexes with Schiff base derived from amoxicillin with two aldehydes: p-chlorobenzaldehyde and cinnamaldehyde, these metal complexes showed enhanced antimicrobial activity than the one that was found for free Schiff bases. The prepared complexes have been investigated and found to have an octahedral geometries (Joshi et al., 2011).

Schiff base complexes were formed recently, that derived from the amoxicillin with 4-dimethylamino benzaldehyde, it found that the prepared compounds (complexes) have good antibacterial activity when compared to the parent control (AlNoor et al., 2014).

\section{Experimental}

\section{A-Chemicals and Apparatus}

Chemicals acquired from Aldrich, Fluka, Alfa aesar and B.D.H. utilized without filtration. Melting point were determined by the open capillary method using hot stage Gallenkamp melting point apparatus and was uncorrected. ${ }^{1} \mathrm{H}-\mathrm{NMR}$ spectra was recorded on Bruker $400 \mathrm{MHz}$ spectrometers with tri methyl silane (TMS) as an inner reference utilizing deuterated di methyl sulfoxide (DMSO-d6) as solvent. Infra-red spectra were recorded with $\mathrm{KBr}$ disk utilizing an FTIR spectrophotometer Shimadzu model 8300 in range (4000-400) $\mathrm{cm}^{-1}$.

The Uv-Vis. spectra were measured using Shimadzu Uv-Vis 160A Ultra-violet Spectrophotometer in the range (200-1100) $\mathrm{nm}$. Thermal analysis TGA was performed with4000 Perkin-Elmer thermal analyzer maintained at a $2000{ }^{\circ} \mathrm{C} \mathrm{min}^{-1}$ heating rate. Elemental analysis techniques were recorded on EuroEA Elemental Analyzer $2000{ }^{\circ} \mathrm{C}$. The metal content of the complexes was measured using flame-atomic absorption technique by Agilent Varian AA 240 FS. 


\section{B-Preparations}

\section{1-synthesis of the Ligands $\left[L_{1}\right]$ and $\left[L_{2}\right]$}

2 mmole of 6-APA was dissolved in $10 \mathrm{ml}$ of absolute ethanol then mixed with $1 \mathrm{mmole}$ of terephthaladehyde or glyoxal and the reaction was refluxed for 4 hours with stirring to prepare $\mathrm{L}_{1}$ and $\mathrm{L}_{2}$ respectively. The proper $p H$ was adjusted to $\approx 4$ (Sykes P., 1985) by the addition of several drops of glacial acetic acid (the process followed up by $p H$ paper test).

A precipitates were formed after evaporation of the solvent and recrystallized by using diethyl ether and ethanol solvents to give the titled compounds after filtration and air drying.

\section{2-Mole-ratio method}

The mole-ratio method were followed to determine the metal: ligand $[\mathrm{M}: \mathrm{L}]$ ratio in absolute ethanol as solvent. The results suggested that the metal to ligand ratio was [2:1] [M:L] for complexes.

\section{3-Synthesis of $\left[L_{1}\right]$ and $\left[L_{2}\right]$ complexes}

$1 \mathrm{mmole}$ of $\mathrm{L}_{1}$ or $\mathrm{L}_{2}$ dissolved in $10 \mathrm{ml}$ absolute ethanol then mixed with 2 mmole of the desired metal ion $\left(\mathrm{CoCl}_{2} \cdot 6 \mathrm{H}_{2} \mathrm{O}, \mathrm{CuCl}_{2} \cdot 2 \mathrm{H}_{2} \mathrm{O}\right.$ or $\left.\mathrm{ZnCl}_{2} \cdot 6 \mathrm{H}_{2} \mathrm{O}\right)$. The mixture was refluxed for 2 hours; the resulting precipitates were formed after evaporation of the solvent and recrystallized by using diethyl ether and ethanol solvents to give the following complexes:

$\left[\mathrm{Co}_{2} \mathrm{~L}_{1} \mathrm{Cl}_{4} 4 \mathrm{H}_{2} \mathrm{O}\right] .2 \mathrm{H}_{2} \mathrm{O}\left(\mathrm{A}_{1}\right)$, $\left[\mathrm{Cu}_{2} \mathrm{~L}_{1} \mathrm{Cl}_{4} 4 \mathrm{H}_{2} \mathrm{O}\right] \cdot \mathrm{H}_{2} \mathrm{O}\left(\mathrm{A}_{2}\right)$,

$\left[\mathrm{Zn}_{2} \mathrm{~L}_{1} \mathrm{Cl}_{4} 4 \mathrm{H}_{2} \mathrm{O}\right]\left(\mathrm{A}_{3}\right)$,

$\left[\mathrm{Co}_{2} \mathrm{~L}_{2} \mathrm{Cl}_{4} 4 \mathrm{H}_{2} \mathrm{O}\right] .2 \mathrm{H}_{2} \mathrm{O}\left(\mathrm{B}_{1}\right)$,

$\left[\mathrm{Cu}_{2} \mathrm{~L}_{2} \mathrm{Cl}_{4} 4 \mathrm{H}_{2} \mathrm{O}\right] \cdot \mathrm{H}_{2} \mathrm{O}\left(\mathrm{B}_{2}\right)$, $\left[\mathrm{Zn}_{2} \mathrm{~L}_{2} \mathrm{Cl}_{4} 4 \mathrm{H}_{2} \mathrm{O}\right] \cdot \mathrm{H}_{2} \mathrm{O}\left(\mathrm{B}_{3}\right)$.
Physical properties and yield percentage of all prepared compounds were listed in Table 1.

\section{Antimicrobial Activity}

In this study, the synthesized compounds were evaluated for their in vitro antimicrobial activity against some of the pathogenic bacteria, two bacterial species were used: Gram positive (Staphylococcus aureus) and Gram negative bacteria (pseudomonas aeruginosa).

The minimum inhibition concentration (MIC) was followed up for precursor 6APA as a leading compound as long as the penicillin derivatives can be synthesized from the parent 6-APA.

Concentration $10^{-3} \mathrm{M}$ was the MIC of 6-APA depending on dilution method and considered as the proper concentration for all the prepared compounds.

The bioassays were performed in duplicate with three repetitions for each bacterial strain; upon the detection of an error.

\section{Antibacterial Evaluation}

The suspension Medium inoculated bacteria were diluted by $1 / 100$ using normal-saline solution with concentration of $0.85 \%$ to prevent crowded growth. $0.1 \mathrm{ml}$ of the bacteria diluted suspension was transported to each plate and spread through the use of sterilized cotton on test medium surface. These Plates were left for (15-20) min. at $37^{\circ} \mathrm{C}$ to make absorption. The plates of Mueller Hinton agar were inoculated by Staphylococcus aureus and Pseudomonas aeruginosa. In each medium one pore was made by the use of a sterile dry rod with a diameter of $4 \mathrm{~mm}$, then the solutions of $10^{-}$ ${ }^{3} \mathrm{M}$ concentration of the prepared 
compounds were added by the use of fixed amounts of $0.1 \mathrm{ml}$ from each solution in one pore, these plates were incubated at $37 \mathrm{C}^{0}$ for $24 \mathrm{hrs}$. After the incubation, the zone of inhibition was measured for each pore using a ruler in $(\mathrm{mm})$. The zone of inhibition can be defined as the transparent area which surrounds the disc including the diameter of the disc that lacks to bacterial growth. The bacteria was sensitive, mean-sensitive or resistant depending on inhibition zone.

\section{Results and Discussion}

Our study is to illustrate the behavior of the synthesized multidentate ligands $\mathrm{L}_{1}$ and $\mathrm{L}_{2}$ towards the metal ion to synthesized the desired complexes $\mathrm{A}_{1}-\mathrm{A}_{3}$ and $\mathrm{B}_{1}-\mathrm{B}_{3}$ respectively. The property of several coordination sites were discussed to figure out the probable path of the ligand during the reaction with metal ion. The ligand expected to flip around or polymerized due to the bifunctional property or using another mole ratio like [2:2] [M:L] rather than the suggested one[2:1] [M:L] in complexes.

In addition to the preparation of the complicated compound, the possession of the two antibacterial part derived us to discover the double action as drugs in vitro and make comparison between the parent 6APA and the synthesized compounds.

The final suggested structure of our task compounds were presented in Figure 1. and 2 depending on the usual available techniques such as metal and elemental analysis, thermal analysis, conductivity and mole ratio method.

\section{Infrared spectra}

The infrared spectral values of $\mathrm{L}_{1}, \mathrm{~L}_{2}$ and their complexes are presented in Table $2 . \mathrm{L}_{1}$ and $\mathrm{L}_{2}$ exhibit a strong band at $1697 \mathrm{~cm}^{-1}$ and $1681 \mathrm{~cm}^{-1}$ respectively which could be attributed to carboxylic carbonyl $\mathrm{C}=\mathrm{O}$. This band shifted to lower wave numbers in all complexes $A_{1}-A_{3}$ and $B_{1}-B_{3}$ by $(5-12) \mathrm{cm}^{-1}$ and $(7-11) \mathrm{cm}^{-1}$ respectively, indicating that carboxylic group is involved in complex formation.

The coordination through the oxygen atom in $\mathrm{C}=\mathrm{O}$ are further supported by the occurrences of new bands around $545 \mathrm{~cm}^{-1}$ in the spectra of the mentioned complexes which may be assigned to $\mathrm{M}-\mathrm{O}$ bond.

The band at $1732 \mathrm{~cm}^{-1}$ is due to $\beta$-Lactam carbonyl $\mathrm{C}=\mathrm{O}$ group for both ligands. Since this band does not shifted, this means the oxygen of the carbonyl $\mathrm{C}=\mathrm{O}$ does not participate in the coordination, but it indicate the participation of the nitrogen atom of the $\beta$-lactam which is situated in a favorable position to give 5-memberd ring beside it bended out of plane of the other three carbon atoms in the $\beta$-lactam ring (Radha Raman et al., 1998).

Bands at (475-585) $\mathrm{cm}^{-1}$ range in the spectra of the complexes which may be assigned to M-N bond (Cramer Roger et al., 1981). $\mathrm{L}_{1}$ and $\mathrm{L}_{2}$ also shows a strong bands at 1635 $\mathrm{cm}^{-1}$ and $1654 \mathrm{~cm}^{-1}$ respectively which assigned to imine $\mathrm{C}=\mathrm{N}$ group (Socrates, 1980; Kazuo Nakamoto, 1997).

However, this band does not affected with complexation. Therefore the coordination could be through carboxylic and $\beta$-lactam nitrogen with 5-memberd ring.

\section{Electronic Spectra}

The electronic absorption spectra of $\mathrm{Co}(\mathrm{II})$, $\mathrm{Cu}(\mathrm{II})$ and $\mathrm{Zn}$ (II) complexes of [ $\left.\mathrm{L}_{1}\right]$ and $\left[\mathrm{L}_{2}\right]$ were recorded in absolute ethanol as solvent and concentration $10^{-3} \mathrm{M}$ in the range (2001100) $\mathrm{nm}$.

The electronic spectra of $\mathrm{Co}$ (II) complexes in octahedral geometries display three bands 
(Nicholls D.,1973 Huheay J.E.,1983) which may be assigned to :

$v_{1}:{ }^{4} \mathrm{~T}_{1} \mathrm{~g}(\mathrm{~F}) \rightarrow{ }^{4} \mathrm{~T}_{2} \mathrm{~g}(\mathrm{~F})(7000-12000) \mathrm{cm}^{-1}$,

$v_{2:}{ }^{4} \mathrm{~T}_{1} \mathrm{~g}(\mathrm{~F}) \rightarrow{ }^{4} \mathrm{~A}_{2} \mathrm{~g}(\mathrm{~F})\left(14000-16000^{-1}\right) \mathrm{cm}^{-1} \&$ $v_{3}:{ }^{4} \mathrm{~T}_{1} \mathrm{~g}(\mathrm{~F}) \rightarrow{ }^{4} \mathrm{~T}_{1} \mathrm{~g}(\mathrm{P})(17000-21000) \mathrm{cm}^{-1}$

The values of the electronic assignment if $A_{1}$ and $B_{1}$ were with a good agreement to the range reported for octahedral geometry. All the expected values were appeared in the spectrum accept $\mathrm{v}_{1}$ was obscured and calculated with the other parameters $(\mathrm{Dq}, \mathrm{B}$, $\mathrm{B}^{\prime}$ and $\beta$ ).

The $\mathrm{Cu}(\mathrm{II})$ complexes in octahedral shape showed one broad peak corresponding to the transition ${ }^{2} \mathrm{Eg} \rightarrow{ }^{2} \mathrm{~T}_{2} \mathrm{~g} \quad$ (Lever,1987). The complexes $\mathrm{A}_{2}$ and $\mathrm{B}_{2}$ were with similar peaks range suggesting the distorted octahedral geometry.

The spectrum of $\mathrm{Zn}$ (II) complexes $\mathrm{A}_{3}$ and $\mathrm{B}_{3}$ belongs to $\mathrm{d}^{10}$ system that did not show d-d electronic transitions. This is in accordance with the results recorded in reference (Green wood, 1998).

Finally Table 3 shows assignment, structure and calculated parameters along with electronic spectral data

\section{${ }^{1}$ H-NMR spectra}

The ${ }^{1} \mathrm{H}-\mathrm{NMR}$ spectra of ligand $\mathrm{L}_{1}$ in DMSO-d6 solvent shows a singlet peak at $\delta$ $=10.33$ ppm equivalent two protons of $\mathrm{O}-\mathrm{H}$ of carboxylic acid. The signal obtained at $\delta$ $=8.36 \mathrm{ppm}$ was assigned for singlet peak due to two protons of imine group $\mathrm{N}=\mathrm{C}-\mathrm{H}$. The multiplet signals obtained in the range $\delta=(7.9-7.1) \mathrm{ppm}$ is due to aromatic hydrogen of carbons.

A doublet peak given by $\mathrm{CO}-\mathrm{CH}$ group of $\beta$-lactam ring appeared at the range $\delta=(4.6-$
4.1) ppm. $\mathrm{S}-\mathrm{CH}$ group on the dihydrothiazine ring was observed in the range $\delta=(2.90-3.66) \mathrm{ppm}$ as doublet peak.

Finally a single peak appeared at $\delta=1.57$ ppm could be attributed to methyl groups of 5-membered dihydrothiazine ring.

${ }^{1} \mathrm{H}-\mathrm{NMR}$ spectrum of $\mathrm{L}_{2}$ in DMSO-d6 showed signal at $\delta=11.2 \mathrm{ppm}$ of $\mathrm{O}-\mathrm{H}$ of carboxylic acid. The singlet peak obtained at $\delta=8.46 \mathrm{ppm}$ was due to two proton of imine group $\mathrm{CH}=\mathrm{N}$ in the ligand. This gives an evidence of the formation of imine group.

A doublet peak given by $\mathrm{CO}-\mathrm{CH}$ of $\beta$ lactam ring appeared at the range $\delta=(4.1$ 4.7) ppm. S-CH group on the dihydrothiazine ring was observed in range $\delta=(3.23-3.66)$ ppm. Finally a single peak at $\delta=1.57 \mathrm{ppm}$ could be attributed to methyl groups of 5-membered dihydrothiazine ring.

The ${ }^{1} \mathrm{H}-\mathrm{NMR}$ spectral data of $\mathrm{L}_{1}$ and $\mathrm{L}_{2}$ ligands were compared with that reported in literatures (Parikh, 1980; Silverstein et al., 1980; Al-Noor et al., 2014). The comparsion of data showed a good agreement and similarity.

\section{Thermal analysis}

The Thermal behavior of the complex was studied using thermal gravimetric analysis (TGA) .The thermal decomposition data of complexes were shown in Table 4. The decompositions of $\mathrm{A}_{1}$ and $\mathrm{B}_{2}$ complexes in air occur in four or three steps. According to the mass losses, the following degradation patterns might illustrate the proposed structures of the complexes. All the compounds decompose step by step upon time that started by dehydration process, lattice water molecules decompose first followed by leaving the coordinated water molecules. In the second step, weight loss 
were observed as gases such as leaving carbon monoxide (CO), hydrochloric acid $(\mathrm{HCl})$, chlorine $\left(\mathrm{Cl}_{2}\right)$ and hydrogen $\left(\mathrm{H}_{2}\right)$ gases (Gehad et al., 2006; Mostafa et al., 2012).

On the final steps during temperature raise, $\mathrm{A}_{1}$ and $\mathrm{B}_{2}$ complexes loss their ligand parts (Ketan, 2012; Aurora Reiss et al., 2009) leaving the metal oxide $\left(\mathrm{M}_{2} \mathrm{O}\right)$ residue fragments at the end (Liu et al., 2012, 2015; Rehali).
In conclusion, according to the above results we can conclude that the suggested structure for all complexes could be in distorted octahedral geometries with mole ratio [2:1] $[\mathrm{M}: \mathrm{L}]$ and general formula $\left[\mathrm{M}_{2} \mathrm{~L}_{1} \mathrm{Cl}_{\mathrm{X}}\right.$ $\left.\left(\mathrm{H}_{2} \mathrm{O}\right)_{\mathrm{Y}}\right] \cdot \mathrm{ZH}_{2} \mathrm{O}$ (x,y, z) : Natural number, that the ligands interacted with the metal ion in five membered ring pattern through carboxylic acid and cyclic amide nitrogen ( $\beta$-lactam), beside water molecules and chloride ions to satisfy the six-coordination number.

Table.1 Analytical and physical data of ligands and their metal complexes

\begin{tabular}{|c|c|c|c|c|c|c|c|c|c|c|}
\hline \multirow{2}{*}{ Symb. } & \multirow{2}{*}{ Empirical formula } & \multirow[t]{2}{*}{ Color } & \multirow{2}{*}{$\begin{array}{l}\text { M.p } p^{\circ} \mathrm{c} \\
(\text { dec. })^{\circ} \mathrm{c}\end{array}$} & \multirow{2}{*}{$\underset{\Omega^{-1} \mathrm{~cm}^{2} \mathrm{~mol}^{-1}}{\Lambda \mathrm{m}}$} & \multirow{2}{*}{ Yield \% } & \multicolumn{5}{|c|}{$\begin{array}{l}\text { Elemental and metal analysis } \\
\text { Found (Calc.) }\end{array}$} \\
\hline & & & & & & $\mathrm{C} \%$ & H\% & N\% & S\% & M\% \\
\hline \multirow{2}{*}{$\mathbf{L}_{1}$} & \multirow{2}{*}{$\mathrm{C}_{24} \mathrm{H}_{26} \mathrm{~N}_{4} \mathrm{O}_{6} \mathrm{~S}_{2}$} & \multirow{2}{*}{ Orange } & \multirow{2}{*}{ 224-226 } & \multirow[t]{2}{*}{5.3} & \multirow{2}{*}{81} & 54.14 & 5.02 & 10.23 & 11.92 & - \\
\hline & & & & & & $(\mathbf{5 4 . 3 3 )}$ & $(4.90)$ & $(10.57)$ & (12.07) & - \\
\hline \multirow[b]{2}{*}{$\mathbf{A}_{1}$} & \multirow[b]{2}{*}[\mathrm{Co}_{2}\mathrm{L}_{1}(\mathrm{H}_{2}\mathrm{O})_{4}\mathrm{Cl}_{4}]{$\cdot 2 \mathrm{H}_{2} \mathrm{O}$} & \multirow[b]{2}{*}{$\begin{array}{l}\text { Pale } \\
\text { green }\end{array}$} & \multirow[b]{2}{*}{ 240dec. } & \multirow{2}{*}{8.7} & \multirow[b]{2}{*}{72} & 31.90 & 4.28 & 5.98 & 7.27 & 12.89 \\
\hline & & & & & & (32.07) & $(4.23)$ & $(6.23)$ & (7.12) & (13.14) \\
\hline \multirow{2}{*}{$\mathbf{A}_{2}$} & \multirow{2}{*}[\mathrm{Cu}_{2}\mathrm{L}_{1}(\mathrm{H}_{2}\mathrm{O})_{4}\mathrm{Cl}_{4}]{$\cdot \mathrm{H}_{2} \mathrm{O}$} & \multirow[t]{2}{*}{ Green } & \multirow[t]{2}{*}{ 270dec. } & \multirow[t]{2}{*}{7.2} & \multirow[t]{2}{*}{80} & 32.17 & 4.09 & 6.15 & 7.05 & 14.01 \\
\hline & & & & & & (32.39) & $(4.04)$ & $(6.29)$ & $(7.19)$ & $(14.28)$ \\
\hline \multirow[b]{2}{*}{$A_{3}$} & \multirow[b]{2}{*}[\mathrm{Zn}_{2}\mathrm{L}_{1}(\mathrm{H}_{2}\mathrm{O})_{4}\mathrm{Cl}_{4}]{} & \multirow[b]{2}{*}{ Orange } & \multirow[b]{2}{*}{$241-243$} & \multirow[b]{2}{*}{5.8} & \multirow[b]{2}{*}{77} & 32.66 & 3.95 & 6.32 & 7.03 & 14.78 \\
\hline & & & & & & (32.91) & (3.88) & (6.41) & (7.31) & (14.97) \\
\hline \multirow{2}{*}{$\mathbf{L}_{2}$} & \multirow{2}{*}{$\mathrm{C}_{18} \mathrm{H}_{22} \mathrm{~N}_{4} \mathrm{O}_{6} \mathrm{~S}_{2}$} & \multirow{2}{*}{ Yellow } & \multirow{2}{*}{$231-233$} & & & 47.33 & 4.45 & 12.10 & 14.30 & - \\
\hline & & & & 4.7 & 84 & (47.56) & (4.88) & $(\mathbf{1 2 . 3 3})$ & (14.11) & - \\
\hline $\mathbf{B}_{1}$ & 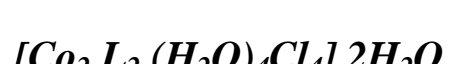 & Pale & $158-160$ & 6.5 & 78 & 26.12 & 4.25 & 6.98 & 7.58 & 14.28 \\
\hline D1 & {$\left[\mathrm{CO}_{2} \mathrm{~L}_{2}\left(\mathrm{H}_{2} \mathrm{U}\right)_{4} \mathrm{C} \mathrm{C}_{4}\right] \cdot 2 \mathrm{H}_{2} \mathrm{U}$} & Green & & & & $(26.27)$ & (4.13) & $(6.81)$ & (7.78) & (14.35) \\
\hline & & & & 67 & & 26.34 & 4.06 & 7.02 & 7.28 & 15.45 \\
\hline $\mathbf{B}_{2}$ & {$\left[\mathrm{Cu}_{2} \mathrm{~L}_{2}\left(\mathrm{H}_{2} \mathrm{O}\right)_{4} \mathrm{Cl}_{4}\right] \cdot \mathrm{H}_{2} \mathrm{O}$} & Green & 172dec. & & 74 & (26.56) & (3.93) & $(6.88)$ & (7.87) & (15.62) \\
\hline & {$\left[\mathrm{Zn} n_{2} L_{2}\left(H_{2} O\right)_{1} \mathrm{C}\right.$} & & & 5.6 & & 26.61 & 3.71 & 6.52 & 7.74 & 15.93 \\
\hline $\mathbf{B}_{3}$ & & Yellow & $252-254$ & & 79 & $(26.43)$ & (3.91) & $(6.85)$ & (7.83) & (16.03) \\
\hline
\end{tabular}

$\Lambda m=$ Molar Conductivity, dec. = decomposition, Calc. $=$ calculation 
Table.2 FT-IR Spectral bands of the Prepared Compounds

\begin{tabular}{|c|c|c|c|c|c|c|c|c|c|}
\hline Compound & $U(\mathrm{O}-\mathrm{H})$ & $\begin{array}{c}U(\mathrm{C}-\mathrm{H}) \\
\text { Aliphatic } \\
\text { Aromatic }\end{array}$ & $\begin{array}{c}U(\mathrm{C}=\mathbf{0}) \\
\boldsymbol{\beta} \text {-lactam }\end{array}$ & $\begin{array}{c}U(\mathrm{C}=\mathbf{0}) \\
\text { Carboxylic }\end{array}$ & $\begin{array}{c}U(\mathrm{C}=\mathrm{N}) \\
\text { Imine }\end{array}$ & $\begin{array}{l}U(\mathrm{C}=\mathrm{C}) \\
\text { Aromatic }\end{array}$ & $U(\mathrm{C}-\mathrm{N})$ & $U(\mathrm{C}-\mathrm{O})$ & $\begin{array}{l}U(\mathrm{M}-\mathrm{N}) \\
U(\mathrm{M}-\mathrm{O})\end{array}$ \\
\hline $\mathbf{L}_{1}$ & 3383 & $\begin{array}{l}3078 \\
2974\end{array}$ & 1732 & 1697 & 1635 & 1608 & 1300 & 1211 & - \\
\hline $\mathbf{A}_{1}$ & 3402 & $\begin{array}{l}3078 \\
2978\end{array}$ & 1732 & 1685 & 1635 & 1608 & 1330 & 1207 & $\begin{array}{l}505 \\
447\end{array}$ \\
\hline $\mathbf{A}_{2}$ & 3371 & $\begin{array}{l}3167 \\
2985\end{array}$ & 1732 & 1689 & 1635 & 1600 & 1338 & 1199 & $\begin{array}{l}493 \\
412\end{array}$ \\
\hline $\mathbf{A}_{3}$ & 3409 & $\begin{array}{l}3205 \\
2974\end{array}$ & 1732 & 1693 & 1635 & 1608 & 1307 & 1245 & $\begin{array}{l}462 \\
405\end{array}$ \\
\hline $\mathbf{L}_{2}$ & 3340 & $\begin{array}{c}- \\
2974\end{array}$ & 1732 & 1681 & 1654 & - & 1338 & 1215 & - \\
\hline $\mathbf{B}_{1}$ & 3379 & $\begin{array}{c}- \\
2975\end{array}$ & 1732 & 1670 & 1654 & - & 1373 & 1215 & $\begin{array}{l}555 \\
428\end{array}$ \\
\hline $\mathbf{B}_{2}$ & 3437 & $\begin{array}{c}- \\
2978\end{array}$ & 1732 & 1670 & 1654 & - & 1296 & 1207 & $\begin{array}{l}462 \\
420\end{array}$ \\
\hline $\mathbf{B}_{3}$ & 3409 & $\begin{array}{c}- \\
2958\end{array}$ & 1732 & 1674 & 1654 & - & 1338 & 1215 & $\begin{array}{l}478 \\
410\end{array}$ \\
\hline
\end{tabular}


Table.3 Electronic Spectral data of ligand metal complexes

\begin{tabular}{|c|c|c|c|c|c|c|c|c|}
\hline symb. & $\lambda \boldsymbol{n m}$ & $v^{c^{-1}}$ & Assignments & $\boldsymbol{B}$ & $B^{\prime}$ & $\boldsymbol{B}$ & $10 D q$ & $\begin{array}{l}\text { Suggested } \\
\text { Structure }\end{array}$ \\
\hline $\mathbf{A}_{1}$ & $\begin{array}{c}238 \\
575 \\
657 \\
1388\end{array}$ & $\begin{array}{c}42,016 \\
17,391 \\
15,220 \\
7201(\text { Cal. })\end{array}$ & $\begin{array}{c}\pi \rightarrow \pi^{*}, n \rightarrow \pi^{*} \\
{ }^{4} T_{1} g(F) \rightarrow{ }^{4} T_{1} g^{4}(P) \\
{ }^{4} T_{1} g(F) \rightarrow{ }^{4} A_{2} g^{4}(F) \\
{ }^{4} T_{1} g(F) \rightarrow{ }^{4} T_{2} g^{4}(F)\end{array}$ & 1128 & 758 & 0.65 & 8019 & $\begin{array}{l}\text { Distorted } \\
\text { Octahedral }\end{array}$ \\
\hline $\mathbf{A}_{2}$ & $\begin{array}{l}241 \\
340 \\
654\end{array}$ & $\begin{array}{l}41,493 \\
29,411 \\
15,290\end{array}$ & $\begin{array}{c}\pi \rightarrow \pi^{*} \\
n \rightarrow \pi^{*} \\
{ }^{2} E g \rightarrow T^{2} T_{2} g\end{array}$ & - & - & - & & $\begin{array}{c}\text { Distorted } \\
\text { Octahedral }\end{array}$ \\
\hline $\mathbf{A}_{3}$ & $\begin{array}{l}257 \\
307\end{array}$ & $\begin{array}{l}38,910 \\
32,573\end{array}$ & $\begin{array}{c}\boldsymbol{\pi} \rightarrow \boldsymbol{\pi}^{*} \\
\boldsymbol{n} \rightarrow \boldsymbol{\pi}^{*}\end{array}$ & - & - & - & & $\begin{array}{c}\text { Distorted } \\
\text { Octahedral }\end{array}$ \\
\hline $\mathbf{B}_{1}$ & $\begin{array}{c}214 \\
539 \\
652 \\
1372\end{array}$ & $\begin{array}{c}46,729 \\
18,552 \\
15,337 \\
7285 \text { (Cal.) }\end{array}$ & $\begin{array}{c}\pi \rightarrow \pi^{*}, n \rightarrow \pi^{*} \\
{ }^{4} T_{1} g(F) \rightarrow{ }^{4} T_{1} g^{4}(P) \\
{ }^{4} T_{1} g(F) \rightarrow{ }^{4} A_{2} g^{4}(F) \\
{ }^{4} T_{1} g(F) \rightarrow{ }^{4} T_{2} g^{4}(F)\end{array}$ & 1128 & 728.5 & 0.64 & 8052 & $\begin{array}{c}\text { Distorted } \\
\text { Octahedral }\end{array}$ \\
\hline $\mathbf{B}_{2}$ & $\begin{array}{l}234 \\
352 \\
648\end{array}$ & $\begin{array}{l}42,735 \\
28,409 \\
15,432\end{array}$ & $\begin{array}{c}\pi \rightarrow \pi^{*}, n \rightarrow \pi^{*} \\
(C . T) \\
{ }^{2} E g \rightarrow^{2} T_{2} g\end{array}$ & - & - & - & & $\begin{array}{c}\text { Distorted } \\
\text { Octahedral }\end{array}$ \\
\hline $\mathbf{B}_{3}$ & $\begin{array}{l}232 \\
316\end{array}$ & $\begin{array}{l}43,103 \\
31,645\end{array}$ & $\begin{array}{l}\pi \rightarrow \pi^{*} \\
n \rightarrow \pi^{*}\end{array}$ & - & - & - & & $\begin{array}{c}\text { Distorted } \\
\text { Octahedral }\end{array}$ \\
\hline
\end{tabular}


Table.4 Thermo analytical results (TGA) of metal complexes

\begin{tabular}{|c|c|c|c|}
\hline Complexes & TG range $/{ }^{\circ} \mathrm{C}$ & Mass loss\% obs. & Assignments \\
\hline $\mathbf{A}_{1}$ & $\begin{array}{c}0-224 \\
224-248 \\
248-510 \\
510-560 \\
>560\end{array}$ & \begin{tabular}{|c|}
4.22 \\
8.44 \\
59.12 \\
12.66 \\
15.56
\end{tabular} & $\begin{array}{l}-2 \mathrm{H}_{2} \mathrm{O}(\text { lattice }) \\
-4 \mathrm{H}_{2} \mathrm{O}(\text { coordinated }),-2 \mathrm{CO} \\
-2 \mathrm{Cl},-\mathrm{L}_{1} \text { ligand } \\
-2 \mathrm{HCl}-,-2 \mathrm{O} \\
-\mathrm{Co}_{2} \mathrm{O} \text { residue }\end{array}$ \\
\hline $\mathbf{B}_{2}$ & $\begin{array}{c}0-180 \\
180-419 \\
419-561 \\
>561\end{array}$ & $\begin{array}{c}6.89 \\
29.32 \\
48.72 \\
15.07\end{array}$ & $\begin{array}{l}\left.-\mathrm{H}_{2} \mathrm{O} \text { (lattice) },-2 \mathrm{H}_{2} \mathrm{O} \text { (coordinated }\right) \\
-2 \mathrm{H}_{2} \mathrm{O},-4 \mathrm{Cl},-2 \mathrm{H},-2 \mathrm{CO} \\
\mathrm{L}_{2} \text { ligand } \\
-\mathrm{Cu}_{2} \mathrm{O} \text { residue }\end{array}$ \\
\hline
\end{tabular}

Table.5 Antibacterial activity of the prepared compounds

\begin{tabular}{|c|c|c|c|}
\hline No. & Compound & Staphylococcus aureus & Pseudomonas aeruginosa \\
\hline 1 & $\mathbf{L}_{1}$ & ++ & + \\
\hline 2 & $\mathbf{A}_{1}$ & + & -- \\
\hline 3 & $\mathbf{A}_{2}$ & -- & + \\
\hline 4 & $\mathbf{A}_{3}$ & -- & -- \\
\hline 5 & $\mathbf{L}_{2}$ & ++ & + \\
\hline 6 & $\mathbf{B}_{1}$ & + & + \\
\hline 7 & $\mathbf{B}_{2}$ & -- & -- \\
\hline 8 & $\mathbf{B}_{3}$ & -- & -- \\
\hline
\end{tabular}

Key to symbols

$--\quad=$ No inhibition

$+\quad=(5-10) \mathrm{mm}$

$++=(11-20) \mathrm{mm}$ 
Fig.1 Proposed molecular structure of L1 metal complexes.

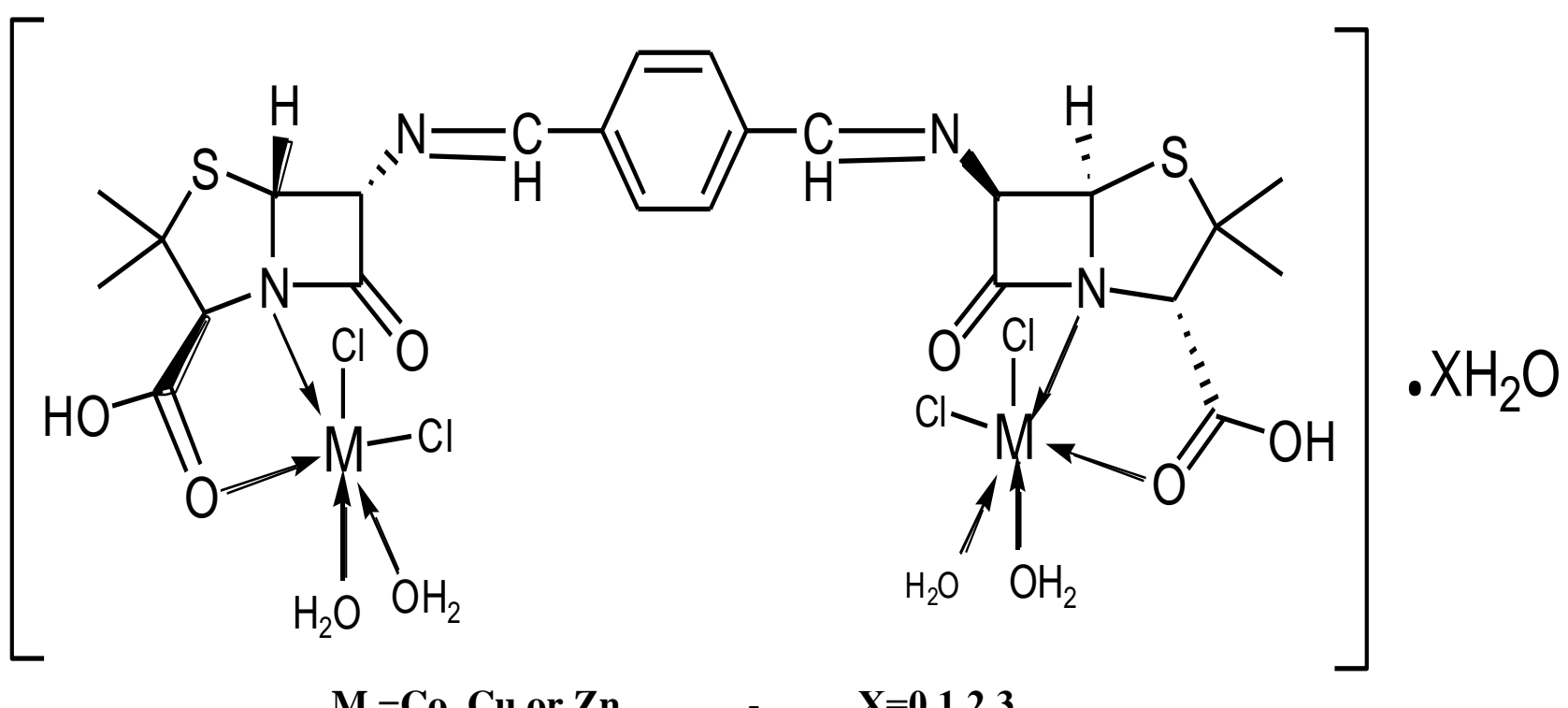

Fig.2 Proposed molecular structure of L2 metal complexes

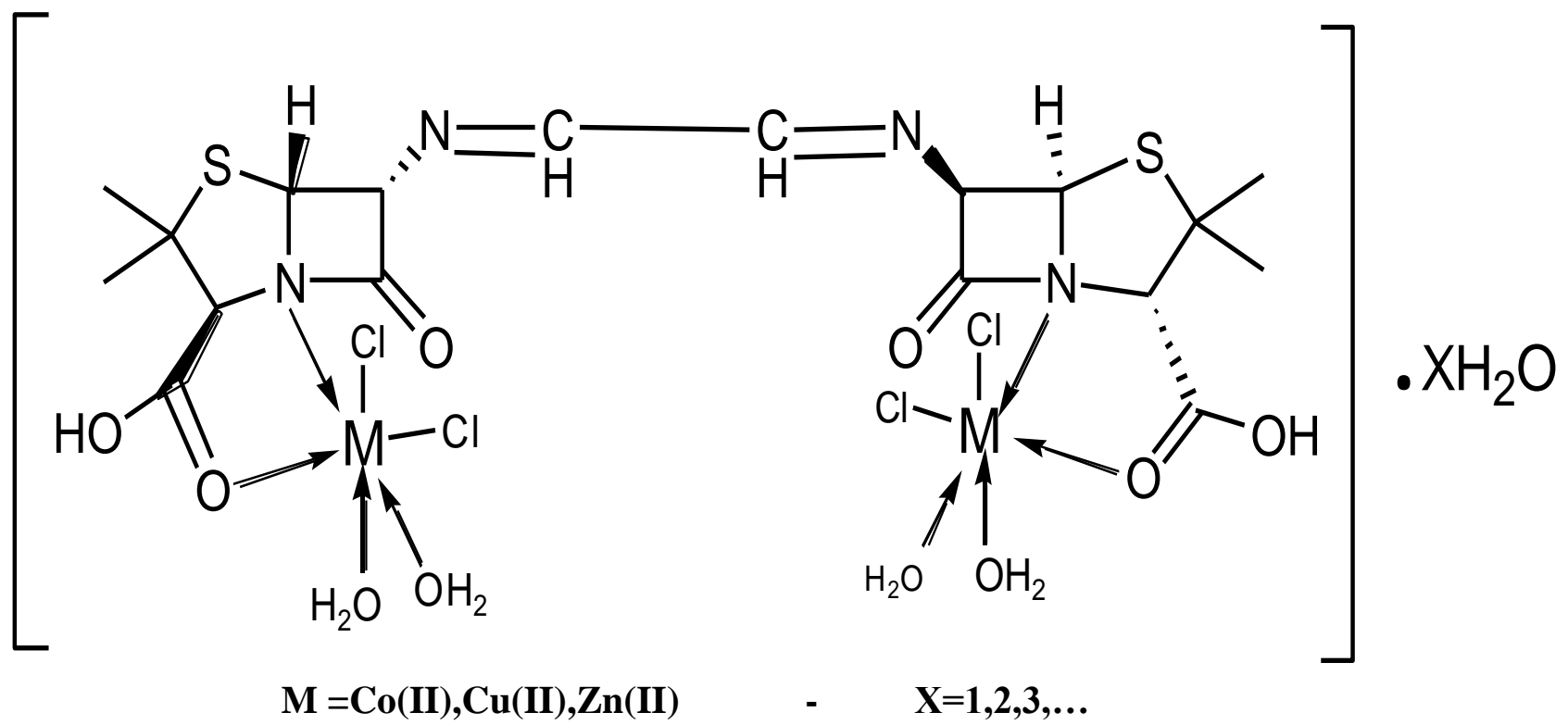

As long as 6-APA is represented as semi synthetic compound for penicillin derivatives synthesis. However; 6-APA located in the terminals of the synthesized compounds will enhance the biological activity due to emerge two beta lactam parts on the same molecule $\mathrm{L}_{1}$ and $\mathrm{L}_{2}$. Furthermore; the presence of the metal ions in the complexes will affect in variable behavior on the final biological screening in vitro.

\section{References}

Al-Noor, H., Taghreed, Manhel, R.A., AlJeboori and Ahmed, T. 2014. Synthesis, characterization and antimicrobial activities of [Fe(II), 
$\mathrm{Co}(\mathrm{II}), \mathrm{Ni}(\mathrm{II}), \mathrm{Cu}(\mathrm{II})$ and $\mathrm{Zn}(\mathrm{II})]$ mixed ligand complexes Schiff base derived from amoxicillin drug and 4(dimethylamino) Benzaldehyde with nicotinamide, J. Chem Pharm. Res., 6, 1225-1231.

Arulmurugan, S., Kavitha, P. Helen and Venkatraman, B.R. 2010. Biological activities of schiff base and its complexes:a review, Rasayan $J$. Chem., 3(3): 385-410.

Aurora Reiss, Stelian Florea, Theodor Caproiu and Nicolae Stanica. 2009. Synthesis, characterization, and antibacterial activity of some transition metals with the Schiff base $\mathrm{N}$-(2-furanylmethylene)-

aminodibenzofuran, Turk. J. Chem., 33, 775-783.

Chohan, Z.H. and Jaffery, M.F. 2000. Synthesis, Characterization and Biological Evaluation of $\mathrm{Co}$ (II), $\mathrm{Cu}(\mathrm{II}), \mathrm{Ni}(\mathrm{II})$ and $\mathrm{Zn}(\mathrm{II})$ Complexes With Cephradine, Metal Based Drugs, 7(5): 265-269.

Cleiton, M., da Silvaa, Daniel, L., da Silvaa, Luzia, V., Modolob, Rosemeire, B. Alvesa, Maria, A. de Resendec, Cleide V.B. Martin,sc, d, Ângelo de Fátimaa. 2011. Schiff bases: A short review of their antimicrobial activities, 1(1): 1-8.

Cramer Roger, E., Douglas M. Ho, William Van Doorn, James, A., Ibers, Ted Norton and Midori, K. 1981. Triphenylmethylphosphoniumtrichloro (caffeine) platinum(II)., J. Inorg. Chem., 20: 2457-2461.

Flynn, H., Edwin. 1972. "Cephalosporins and Penicillins: Chemistry and Biology", $1^{\text {st }}$ ed., Academic Press, New York.

Gehad, G., Mohamed, Mohamed, M., Omar, Ahmed, M., Hindy. 2006. Metal Complexes of Schiff Bases: Preparation, Characterization, and Biological Activity, Turk. J. Chem.,
30: 361-382.

Green wood, N.N. and Earnshow, A. 1998. "Chemistry of the Elements", $2^{\text {nd }}$ ed., John Wiley and sons Inc. 9, 314.

Gupta Radha Raman, Mahendra Kumar, Vandana Gupta, 1998. 'Heterocyclic Chemistry Volume I Principles, Threeand Four-Membered Heterocycles", $1^{\text {st }}$ ed., Springer, Heidelberg, Berlin.

Huheay, J.E. 1983. "Inorganic Chemistry Principles of structures and reactivity", $3^{\text {rd }}$ ed., Harper and Row, New York.

Joshi, S., Pawar, V. and Uma, V. 2011. Synthesis, characterization and biological studies of schiff bases metal complexes Co (II), Zn (II), Ni (II), and $\mathrm{Mn}$ (II) derived from amoxicillin trihydrate with various aldehydes, Int. J. Pharma Bio Sci., 2: 240-250.

Ketan, S., Patel, Jiten, C. Patel, Hitesh, R. Dholariya, Vishal, K., Patel and Kanuprasad, D., Patel. 2012. Synthesis of $\mathrm{Cu}(\mathrm{II}), \mathrm{Ni}(\mathrm{II}), \mathrm{Co}(\mathrm{II})$, and $\mathrm{Mn}$ (II) Complexes with Ciprofloxacin and Their Evaluation of Antimicrobial, Antioxidant and Anti-Tubercular Activity Open J. Metal, 2, 49-59

Lever, A.B.P. 1987. "Inorganic Electronic Spectroscopy", $2^{\text {nd }}$ ed., Elsevier, Amesterdam.

Liu, B.L., Wang, Y.X., Liu, Q.X., and Tao, R.J. 2012. Two New Copper (II) Complexes with the Same NNO Donor Schiff Base Ligand: A Monomer and a Dimer, Z. Natur. Sci, 67: 192-196.

Mostafa, M.H. Khalil, Eman, H., Ismail, Gehad, G., Mohamed, Ehab, M., Zayed and Ahmed Badr. 2012. Synthesis and characterization of a novel schiff base metal complexes and their application in determination of iron in different types of natural water, O. J. Ino. Chem., 2:13-21.

Nicholls, D.1973. "The Chemistry of Iron, Cobalt and Nickel", $1^{\text {st }}$ ed, Pergomon 
press, Oxford, 1090.

Parekh, H.M. and Patel, M.N. 2006. Preparation of Schiff's base complexes of $\mathrm{Mn}(\mathrm{II}), \mathrm{Co}(\mathrm{II}), \mathrm{Ni}(\mathrm{II})$, $\mathrm{Cu}(\mathrm{II}), \mathrm{Zn}(\mathrm{II})$, and $\mathrm{Cd}(\mathrm{II})$ and their spectroscopic, magnetic, thermal, and antifungal studies, Russian J. Coord. Chem., 32, 431-436.

Parikh, V.M. 1980. "Absorption Spectroscopy of Organic Molecules" Wiely, New York.

Przybylski, P., Huczynski, A., Pyta, K., Brzezinski, B., Bartl, F. 2009. Biological properties of schiff bases and azo derivatives of phenols, Curr. Org. Chem., 13(2): 124-148.

Radwan, M., Ali Hameed. 2009. Synthesis and biological activity study of some novel Tri-Schiff's basses derived from 6-aminopenicillanic acid and Triamide containing three 1,3,4thiadiazole unit, A.J. P.S., 6(1): 56-74.

Rehali, H. and Barkat, D. 2015. Extractible Synthesis and Characterization of $\mathrm{Cu}$ (II) Complex with Capric Acid, $J$.
Nanomed. Nanotechnol., 6(6):1-5.

Silverstein, R.M., Basler, G.C. and Morril, T. 1980."Spectroscopic Identification of Organic Compounds" 4th ed., JohnWiely and Sons, Inc. New York,

Sykes, P. 1985." A guide book to mechanism in organic chemistry", $6^{\text {th }}$ ed., Longman scientific and technical, John Wiley and Sons Inc.

Tomi, H., Ivan Rouil, Amer Hasan Abdullah, Ali Hussein Raheemah Al-Daraji and Selma Abdul Rudha Abbas. 2013. Synthesis, characterization and comparative study the antibacterial activities of some imine-amoxicillin derivatives, European J. Chem., 4(2): 153-156.

Zhou Xin, Ling Shao, Zhong Jin, Jian-Bing, Liu Hong Dai Jian-Xin Fan. 2007. "Synthesis and antitumor activity evaluation of some schiff bases derived from 2-aminothiazole derivatives, 18(1): 55-59.

\section{How to cite this article:}

Ammar J. Alabdali and Yasser H. Sabah. 2016. Synthesis, Characterization and Biological Evaluation of Penicillin Derivatives Complexes with Some Transition Metal Ions. Int.J.Curr.Microbiol.App.Sci. 5(12): 321-332. doi: http://dx.doi.org/10.20546/ijcmas.2016.512.035 